\title{
IAMJ
}

INTERNATIONAL

AYURVEDIC

MEDICAL JOURNAL

ISSN: 2320-5091

Impact Factor: 6.719

\section{PHARMACEUTICAL ANALYSIS OF MANIBHADRA YOGA PREPARED WITH DIFFERENT METHODS}

\section{$\underline{\text { Pravin Ramdas Firke }}^{1}, \underline{\text { Anuradha Patil }}^{2}$}

${ }^{1}$ Associate Professor, \& HOD Department of Agadtantra, Krishna Ayurved Medical College, Vadodara, Gujarat, India

${ }^{2}$ Professor, Department of Rasashastra, Hon. Shri. Annasaheb Dange Ayurved Medical College, Ashta, Sangli, Maharashtra, India

Corresponding Author: firkepravin@gmail.com

https://doi.org/10.46607/iamj0309042021

(Published online: April 2021)

Open Access

(C) International Ayurvedic Medical Journal, India 2021

Article Received:19/03/2021 - Peer Reviewed:09/04/2021 - Accepted for Publication:10/04/2021

D) Check for updates

\section{ABSTRACT}

In the present times, awareness regarding preventive healthcare is on the raise, consequently, inclination towards Ayurveda is greater than before. In order to meet the demands for pleasing and agreeable products, there is a need to bring in suitable Ayurvedic products while maintaining their quality and efficacy. Different references for a same product can be seen in various Ayurveda treatises. In Ayurveda, reference of Gudapaka Kalpana (Jaggery confections) was for the first time mentioned in Chakradatta, Arsha Chikitsa (treatment of piles). The main ingredient in this formulation is Jaggery. Hence, such formulations have better palatability than any other Ayurvedic dosage form. Manibhadra Yoga ${ }^{2}$ is one such formulation. The aim of this study was to validate the method of manufacture of Manibhadra Yoga. Hence, three different methods of Gudapaka preparations were adopted in addition to novel methods. The details regarding the same will be discussed during the article.

Keywords: - Manibhadra Yoga, Gudapaka, Granules 


\section{INTRODUCTION}

Some Ayurvedic formulations are not palatable, hence are not accepted easily. e.g. Churna (powder), Swaras (juice), Kalka (paste). Whereas some are prepared with sweetening agents such as Jaggery, sugar for palatability and stability as well. When in a preparation Guda (jaggery) is more in quantity, it is known as Gudapaka Kalpana. eg. Kalyanka Guda, Manibhadra Yoga etc. In today's improved \& modernized lifestyle; unhealthy food habits, mental stress, and busy work schedules have aroused number of Pitta Doshajanya- diseases. These can be alleviated with pacifying formulations like Manibhadra Yoga, which is a mild laxative drug $^{3}$.This yoga is useful in all ages, from children to old age. There are different procedures for preparation of Manibhadra Yoga. But, no work regarding the validation of the method of preparation of Manibhadra Yoga has been done before. Hence, in the present study, Manibhadra Yoga was prepared by different methods and its analytical study was done to validate the process.

Materials: All material required were procured from the market and authenticated.

\section{Ingredients: -}

\begin{tabular}{|l|l|l|l|l|}
\hline Sl.No. & Sanskrit Name & Botanical Name & Part Used & Quantity in gms \\
\hline 1. & Vidanga & Embelia ribes Burm. & Fruit Rind & 25 \\
\hline 2. & Amalaki & Emblica officinalis Gaertn. & Fruit Rind & 25 \\
\hline 3. & Haritaki & Terminali chebula Retz & Fruit Rind & 25 \\
\hline 4. & Trivrutta & Operculina turpethum Linn. & Root bark & 75 \\
\hline 5. & Guda & & & 300 \\
\hline
\end{tabular}

\section{Method of Preparation -}

Manibhadra Yoga was prepared by 3 different methods -

\section{Leha}

2. Modaka

3. Granules

1. Leha Method - This was again done by two methods

a. Preparation by Kwatha ${ }^{4}$ (decoction) Method-

- Coarse powders of all ingredients, except Guda, were taken and Kwatha was prepared with $1200 \mathrm{ml}$ water and reduced to $1 / 4^{\text {th }}$.

- Broken pieces of Guda were added in it \& kept on mild fire while continuously stirring.

- When Guda melted completely, the mixture was filtered through cloth and residue was removed.

- After it attained 2-3 threads consistency heating was stopped \& kept for cooling.

- Brown colored hard, candy-like mass was obtained.

- This was broken and packed in air-tight container and named as Sample A.

b. Preparation by Gudapaka ${ }^{5}$ method -
$>$ Firstly, Guda was broken into small pieces and taken in an inert vessel.

$>150 \mathrm{ml}$ of water was added to soak Guda \& kept on mild fire while continuously stirring.

> When Guda melted completely, the mixture was filtered through cloth and residue was removed.

$>$ The filtrate was again boiled on mild fire until Gudapaka lakshanas ${ }^{6}$ were obtained.

$>$ Maximum temperature maintained was upto $85^{\circ} \mathrm{C}$.

$>$ When 1-2 threads consistency was obtained, fire was put off \& vessel was kept aside.

$>$ The mixture of three Choornas namely, Amalaki, Haritaki, Vidanga, was added in the filtrate\& stirred.

$>$ Later, Trivrutta Choorna was added \& stirred to obtain homogenous mixture.

$>$ On cooling, Leha was filled in a sterile, dry, airtight container \& sealed.

$>$ This was named Sample B.

\section{Preparation of $\mathrm{Modaka}^{7}$}

- Guda was broken into small pieces and taken in an inert vessel. 
- $150 \mathrm{ml}$ of water was added to soak Guda \& kept on mild fire while continuously stirring.

- When Guda melted completely, the mixture was filtered through cloth \& residue was removed.

- The filtrate was again boiled on mild fire until Gudapaka Lakshnas were obtained.

- Maximum temp maintained upto $85^{\circ} \mathrm{C}$.

- When 2-3 threads consistency was obtained, fire was put off $\&$ vessel kept aside.

- Mixture of three Choornas namely Amalaki, Haritaki, Vidanga was added in the filtrate\& stirred.

- Later, Trivrutta Choorna was added \& stirred to obtain a homogenous mixture.

- When the mixture attained a thicker consistency suitable for rolling Vati, Modaka of approximately $10 \mathrm{gm}$ each were rolled out.

- Modaka were filled in sterile, dry, air-tight bottles \& sealed.

- This was named Sample C.

3. Preparation of Granules -

$>$ Guda was broken into small pieces and taken in an inert vessel.
$150 \mathrm{ml}$ of water was added to soak Guda \& kept on mild fire while continuously stirring.

$>$ When Guda melted completely, the mixture was filtered through cloth \& residue was removed.

$>$ The filtrate was again boiled on mild fire until Gudapaka Lakshnas were obtained.

$>$ Maximum temp maintained upto $85^{\circ} \mathrm{C}$.

$>$ When 2-3 threads consistency was obtained, fire was put off \& vessel kept aside.

$>$ Mixture of three Choornas namely Amalaki, Haritaki, Vidanga was added in the filtrate\& stirred.

- Later, Trivrutta Choorna was added \& stirred to obtain a homogenous mixture.

$>$ Mixture was slightly cooled under fan and passed through mesh ${ }^{8}$ to obtain granules.

$>$ Brownish colored granules were collected and kept in hot air oven at $35^{\circ} \mathrm{C}$ for 3 hours to remove excess moisture.

$>$ Granules were filled in sterile, dry, air-tight bottles \& sealed.

This was named Sample D.

Table 1: Observations

\begin{tabular}{|l|l|l|l|l|}
\hline Sr. No. & Sample A & Sample B & Sample C & Sample D \\
\hline Initial weight & $450 \mathrm{gm}$ & $450 \mathrm{gm}$ & $450 \mathrm{gm}$ & $450 \mathrm{gm}$ \\
\hline Water & $1200 \mathrm{ml} \&$ reduced to $1 / 4^{\text {th }}$ & $150 \mathrm{ml}$ & $150 \mathrm{ml}$ & $150 \mathrm{ml}$ \\
\hline Final weight & $290 \mathrm{gm}$ & $472 \mathrm{gm}$ & $430 \mathrm{gm}$ & $424 \mathrm{gm}$ \\
\hline
\end{tabular}

Table 2: Organoleptic Characters

\begin{tabular}{|c|c|c|c|c|}
\hline Tests & Sample A & Sample B & Sample C & Sample D \\
\hline Roopa & Brown, candy like & Black & Brown & Brown, Granular \\
\hline Rasa & Madhur, Tikta, Kashaya & $\begin{array}{l}\text { Madhur, } \\
\text { Kashaya }\end{array}$ & $\begin{array}{l}\text { Madhur, } \\
\text { Kashaya }\end{array}$ & $\begin{array}{l}\text { Madhur, } \\
\text { Kashaya }\end{array}$ \\
\hline Gandha & Guda, Pleasant & Guda, Pleasant & Guda, Pleasant & Guda, Pleasant \\
\hline Sparsha & Hard mass & Semisolid, soft & Hard & Rough, granular \\
\hline Shabda & - & - & Hard, blunt & Crispy \\
\hline
\end{tabular}

Samples B \& D were taken for analysis. Sample A was rejected as it formed an unusually hard mass.
Modaka happened to be hard and too large a size for individual dose. 
Table 3: Result

\begin{tabular}{|l|l|l|l|l|}
\hline Sr.No. & Parameter & Unit & Leha & Granules \\
\hline 1. & Loss on drying at $105^{0} \mathrm{C}$ & $\%$ & 9.78 & 7.05 \\
\hline 2. & Total Ash & $\%$ & 1.98 & 2.32 \\
\hline 3. & Acid insoluble ash & $\%$ & 0.69 & 0.23 \\
\hline 4. & $\mathrm{pH}(5 \%$ soln. $)$ & $\mathrm{g} / \mathrm{cm} 3$ & 1.26 & 3.24 \\
\hline 5. & Bulk density & $\%$ & 90.22 & 0.70 \\
\hline 6. & Total solid content & $\%$ & 21.83 & 92.95 \\
\hline 7. & Alcohol soluble extractive & $\%$ & 27.78 & 5.71 \\
\hline 8. & Water soluble extractive & $\%$ & 34.96 & 53.45 \\
\hline 9. & Total sugar & $\%$ & 6.36 & 28.95 \\
\hline 10. & Reducing sugar & & & 10.80 \\
\hline & Heavy metal & $\mathrm{ppm}$ & Not detected & \\
\hline 11. & Cadmium & $\mathrm{ppm}$ & Not detected & Not detected \\
\hline 12. & Arsenic & $\mathrm{ppm}$ & Not detected & Not detected \\
\hline 13. & Lead & $\mathrm{ppm}$ & Not detected & Not detected \\
\hline 14. & Mercury & & & \\
\hline & Microbial Test & $\mathrm{Cfu} / \mathrm{g}$ & $8 \times 10^{2}$ & $30 \times 10^{2}$ \\
\hline 1. & Total plate count & $\mathrm{Cfu} / \mathrm{g}$ & $6 \times 10^{2}$ & $20 \times 10^{2}$ \\
\hline 2. & Total fungal count & $\mathrm{Cfu} / 25 \mathrm{~g}$ & Absent & Absent \\
\hline 3. & Enterobacter & $\mathrm{Cfu} / 25 \mathrm{~g}$ & Absent & Absent \\
\hline 4. & Salmonella spp. & $\mathrm{Cfu} / \mathrm{g}$ & Absent & Absent \\
\hline 5. & Escherichia coli & & \\
\hline & & & & \\
\hline
\end{tabular}

\section{DISCUSSION}

Manibhadra Yoga is a simple and economically cheaper formulation. All the ingredients are easily available, and the production cost is quite low. Out of the four methods of preparations adopted, Sample A was rejected as it formed an unusually hard mass. Sample B, Leha form, tends to degrade faster due to higher moisture content. Sample C, Modaka, happened to be hard and too large a size for individual dose. Hence, there was a requirement to modify it into a preparation which would be easy to handle, administer, and fix dose according to individual need. Moreover, stability and longer shelf life was another point to be considered. Consequently, it was decided to convert Gudapaka into granules, Sample D. It was found that the granulation process was not very tedious. The final product had a good appearance and therefore more appealing, palatable and would be easier to dispense. On analysis, it was found to have lesser percentage of moisture content, had much higher watersoluble extractives and reducing sugars.

\section{CONCLUSION}

It was concluded that granulation was a better procedure. Dose fixation with granules was easier. Filling and storage were trouble-free. Hence, it was confirmed that granulation of Manibhadra Yoga be taken for further study of process standardization.

\section{REFERENCES}

1. Chakrapani, Chakradutta by P.V. Sharma, Arsha Chikitsa, Chaukhamba Sanskrit Bhavan, Varanasi, 2nd edition

2. Acharya Vagbhata, Ashtang Hrudayam, Sarvangsundar Commentary by Arundatta, Edited by Dr. Kunte, Kushta Chikitsa chapter 19 -31\&32 Chaukhamba publications, Varanasi,reprint 2020 pg no. 713

3. Dr. K.R.C Reddy, Bhaishajya Kalpana Vijnanam, Chapter 16, Chaukhambha Sanskrit Bhavan, Varanasi, Edition 2019, Page no. 554

4. Acharya Sharangdhar, Sharangdhar Samhita, Prof. K.R.Sreekantha Murthy, Kwath Kalpana, Chaukhamba Varanasi, reprint 2017

5. Ayurvedic Formulary of India, Govt. of India, Ministry of Health and Family Welfare, Department of Indian 
System of Medicine and Homeopathy, New Delhi, part- I page no. 149

6. Dr. Indradev Tripathi, Vaidyaka Paribhasa Pradipa, chapter2, Chaukhamba Varanasi, reprint 2007-page no. 55

7. Acharya GovindaDasa, Bhaishajya Ratnavali, Shri. Ambikadatta Shastri, chapter-9 Arsha Chikitsa, Choukhamba Sanskrit Bhavan, Varanasi, Eighteen revised edition 2005-page no.305

8. Dr. Devendra Joshi, Quality control and Standardization of Ayurvedic medicine, Chaukhambha Orientalia, Varanasi, First edition, 2011

\section{Source of Support: Nil \\ Conflict of Interest: None Declared}

How to cite this URL: Pravin Ramdas Firke \& Anuradha Patil: Pharmaceutical Analysis of Manibhadra Yoga Prepared With Different Methods. International Ayurvedic Medical Journal \{online\} 2021 \{cited April, 2021\} Available from: http://www.iamj.in/posts/images/upload/708_712.pdf 